\title{
The X Marks the Spot - Using Geo-games in Teaching Archaeology
}

\author{
Michael Remmy
}

University of Cologne

\begin{abstract}
Digital media have influenced the viewing and learning habits of students for the past decades. At the same time, teaching habits in archaeology have not changed to the same extent.

A popular approach of digital teaching/learning is the use of e-learning portals and gamification methods. The University of Cologne tested this teaching/learning method of geo/educaching in a seminar course at the Archaeological Institute in cooperation with Humanities Computer Science. The main goal of the course was to design virtual geocaching quests that students had to solve by using mobile devices with the setting of Roman Cologne. On the one hand, the development of geo-games allowed the students to use their expertise in digital media while learning archaeological facts. On the other hand, new impulses were given through the change of learning environment.
\end{abstract}

\section{How to cite this book chapter:}

Remmy, M. 2020. The X Marks the Spot - Using Geo-games in Teaching Archaeology. In: Hageneuer, S. (ed.) Communicating the Past in the Digital Age: Proceedings of the International Conference on Digital Methods in Teaching and Learning in Archaeology (12-13 October 2018). Pp. 127-140. London: Ubiquity Press. DOI: https://doi.org/10.5334/bch.j. License: CC-BY 4.0 
After this first test seminar the need for a modular system that could be not only used for archaeological topics but referred to other subjects such as art history, politics or history was seen. The state-funded system Biparcours and the related application Actionbound could be a possible solution and was tested as teaching and learning tool for an archaeological excursion.

This chapter describes the seminars held, the requirements and outcome as well as a future perspective of this method for teaching and learning. The usefulness of this method for excursion seminars will be discussed in particular.

\section{Keywords}

Educaching, Geocaching, Teaching, Gamification, E-learning

\section{Introduction}

Digital media have influenced the viewing and learning habits of students for the past decades. At the same time, teaching habits in archaeology have not changed to the same extent: frontal teaching and lectures are often still seen as best practice (Kelly 2019). The state of the art in didactical methodology is often developed in schools ${ }^{1}$ and finds its way to universities through teachers' seminars and appliance in disciplines of the humanities. This leads to the questions: why is archaeology still dependent on conservative teaching methods and how can geo-games break up this status quo?

\section{Requirements in teaching/learning archaeology}

The public interest in archaeology is as old as the discipline itself. Artists have systematically reproduced ancient art since the 16th century (Vorster et al. 2018a; Vorster 2018b). J.J. Winckelmann, who is seen as the founder of archaeology as a scientific discipline, wanted to broadcast his thesis not only in scientific circles but also to the interested public (Winckelmann 1756; Winckelmann 1760). Famous excavations around the Mediterranean also found their echoes in the collective memories of society and are sometimes manifested in museums (Bernau 2011).

For centuries the education of archaeologists in universities was influenced by documents of archaeological finds and objects such as drawings, etchings, plaster casts and finally photography (Scheding \& Remmy 2014). The general public on the other hand made trips to ancient places. The 'grand tour' of

\footnotetext{
${ }^{1}$ See e.g. Ihamäki (2014) with outdoor learning projects in schools.
} 
English gentlemen in the 18th and 19th centuries was seen as the ultimate way of getting to know ancient cultures and art (Chaney 2000).

The visual aspect of archaeological education is crucial. For decades this information was spread by teachers in archaeology through seminars with frontal teaching and talks.

In particular, the reorganisation of universities' curriculums through the Bologna process prevented interest-oriented teaching and learning: courses have to fit into the curriculum of both teachers and students and the time for studying is regulated (Bloch 2006). This organisational corset is surely one reason for the slow development of archaeological teaching. However, the influence of social changes requires a paradigm shift from teachers as knowledge providers to students as the knowledge and skill acquirer. The student becomes an active part in the application of knowledge and is no longer just a recipient (Mocinic 2012).

\section{E-learning and gamification}

A popular approach to digital teaching/learning is the use of e-learning portals and gamification methods. E-learning portals are currently a 'must have' for organising and teaching in universities. The platforms provide material as well as tasks to successfully pass classes. It is an asset for students to get information whenever and wherever they want. Additionally, the portals support innovative teaching methods like flipped classrooms (Bergmann \& Sams 2012), MOOCs (massive open online courses) (Van Treeck, Himpsl-Gutermann \& Robes 2013) or blended learning (Buchegger et al. 2006), approaches that can have an interactive note. This interaction is supported by the up- and download concepts of tasks, homework etc. However, this flexibility in learning sometimes contradicts the need for contact time between teacher and students within seminars and lectures.

In higher education, a tendency to use gamification approaches in teaching is visible. In this case the broader definition of gamification - 'the application of typical elements of gameplaying (e.g. point scoring, competition with others, rules of play) to other areas of activity, typically as an online marketing technique to encourage engagement with a product or service' (Oxford Dictionaries 2019) - is defined as the teaching/learning method. These methods are strongly influenced by the gaming industry, which invests big money in new developments and techniques.

A part of the creative learning aspect that can be achieved with gamification the motivation and interest of students in these methods - is seen as a big pro. Unfortunately, ineffective use of gamification can lead to the opposite and might trivialise important topics and issues (Hand 2016; Kyriakova, Angelova \& Yordanova 2017). 
In almost all of these cases students learn in a closed environment such as auditoriums or their private rooms. However, researchers from the geographical disciplines started to stress the benefits of learning outside the classrooms while using e-learning approaches (Schleicher 2006).

\section{Geocaching as 'missing link'}

An approach that uses parts of e-learning portals as well as gamification and therefore can be seen as the 'missing link' is geo- or in a specific way educaching. Geocaching originally is an activity that uses a GPS (Curlie 2018) receiver to locate and hide small containers (caches) all over the world. This game was established in the year 2000, when location via GPS became accurate and open for private use. The first cache was placed in Oregon, USA, in May 2000 (Geocaching 2000) and from this moment on the geocaching movement started to spread. With the establishment of smartphones as main communication tool in society the originally analogue activity was transferred into the digital world. The caches are received via smartphones and can represent either different kinds of hints for the next cache or the final point of a quest (Cacher-Reisen 2019). The recreational focus of geocaching was expanded by the educational facet of the game. This emphasis led to the neologism 'educaching' (Brombach 2010; Educaching 2012). This method was tested, evaluated and used successfully in teaching series in schools (Kissinger, Naumann \& Siegmund 2016).

Here especially the outdoor education as an experiential learning approach (Ihamäki 2014: 356-357) has to be seen - the change of learning environments and methods can be a positive impulse for the learning outcome of the user.

Documentation of the use of educaching in universities is rather short. ${ }^{2}$ In a compilation for the Hochschulforum Digitalisierung the whole variety of digital teaching methods in Germany was published with short examples (Wannemacher et al. 2016). Educaching is discussed very briefly, with a small example from the University of Bochum (Wannemacher et al. 2016: 23).

\section{Case studies at Cologne University ${ }^{3}$}

At Cologne University, the educaching method was tested at the Archaeological Institute in cooperation with Humanities Computer Science in two lectures. The main goal of the course was to design virtual geocaching quests that the user had to solve by using mobile devices on an archaeological site. The showcase

\footnotetext{
${ }^{2}$ For one of good example of a course documentation using geocaching see Robison (2011).

${ }^{3}$ Special thanks to Dr Jan Wieners for the joint conduct of the seminar and the students for their openness and feedback.
} 


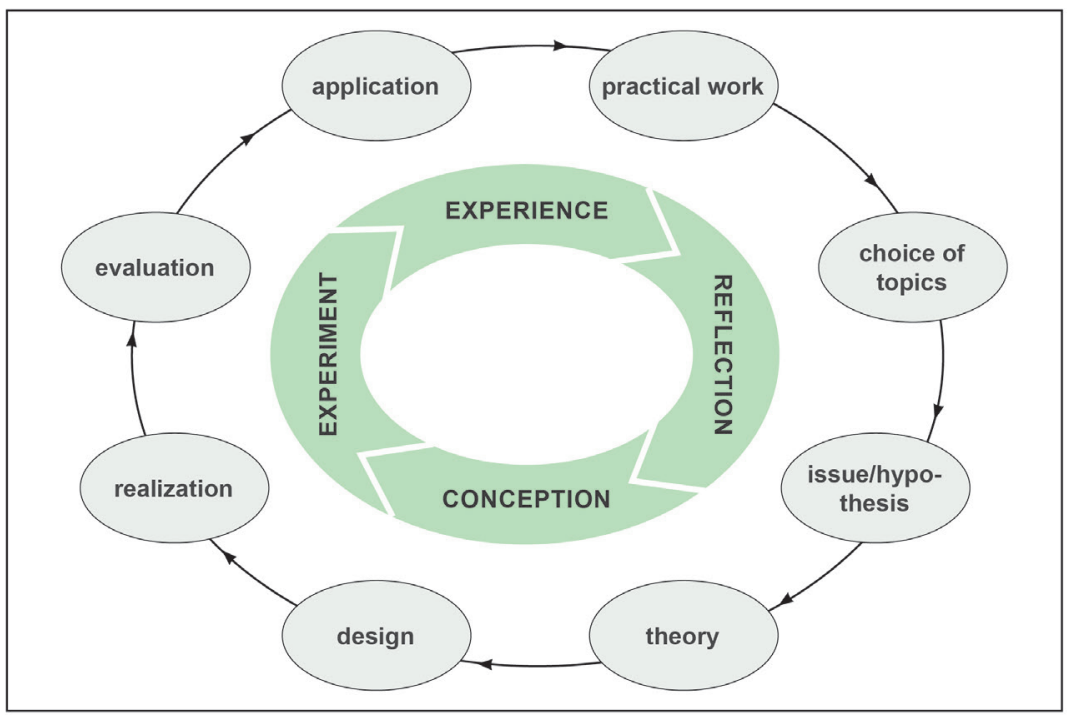

Figure 1: Learning circle of explorative/research-based learning (after Wildt 2009).

was the Roman city of Cologne (Fischer \& Trier 2013). However, the teachers predefined neither the story nor the content.

The composition of the student group was quite heterogeneous. Aside from archaeologists, there was a high percentage (40\%) of computer science students attending the class.

To get the best possible work and learning outcomes for the students the class was divided into groups that represented both disciplines. Working in groups needs not only discipline from students but also micromanagement by teachers. The seminar was structured in input and working phases (sprints) that led to a sprint report. Each member of the group had to report on the progress and the strong/weak points of the sprint. This helps to hold the group together and also to get the students to reflect on their own work.

The didactical concept of explorative or research-based learning (Wildt 2009) was chosen to give the students the most open and creative framework to solve their tasks and represents a learning circle that can be used for further seminars as well (Figure 1).

From the teacher's point of view, five objectives were defined that ideally helped the students to work in the seminar:

- Students should be able to work together with colleagues of other disciplines in order to solve problems and create a product - teamwork.

- Students should be able to use different tools while working on the developments of the product (e.g. Leaflet (Leaflet 2017), GeoJson (GeoJson 2016)) - application. These tools should be open source. 
- Students should be able to organise their own study time and working hours - organisation (Figure 2).

- Students should be able to gather information on Roman life in the city of Cologne - research (Figure 3).

- Students should be able to present their workflow and final product in different media - reflection/presentation.

Within 15 lessons the groups were taught the use of different tools and programs they should use while working on the realisation of their project. On the other hand, there was enough free space for the students to be creative and deal with the execution of the regular sprint tasks.

\section{Outcome}

After the first sprint reports, the different approaches of the three groups emerged.

'Life of Julius' puts the user into the position of a Roman citizen who can climb the cursus honorum (Brennan Carrey 2015) after answering questions on ancient buildings in Cologne (Figure 4). The avatar, called Julius, lives in the city of Cologne and wonders what great achievements the Romans brought into the city. In particular, infrastructure such as the city wall or the temples come into his mind while thinking of this golden age of Cologne. Multiple-choice

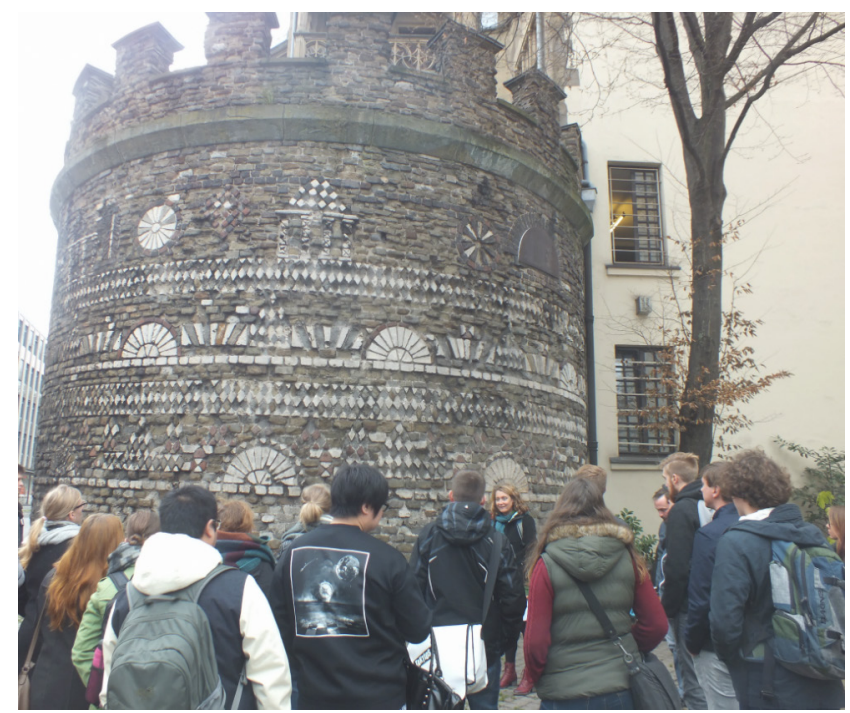

Figure 2: Learning about Roman Cologne at one of the city wall towers. Photo: M. Remmy. 


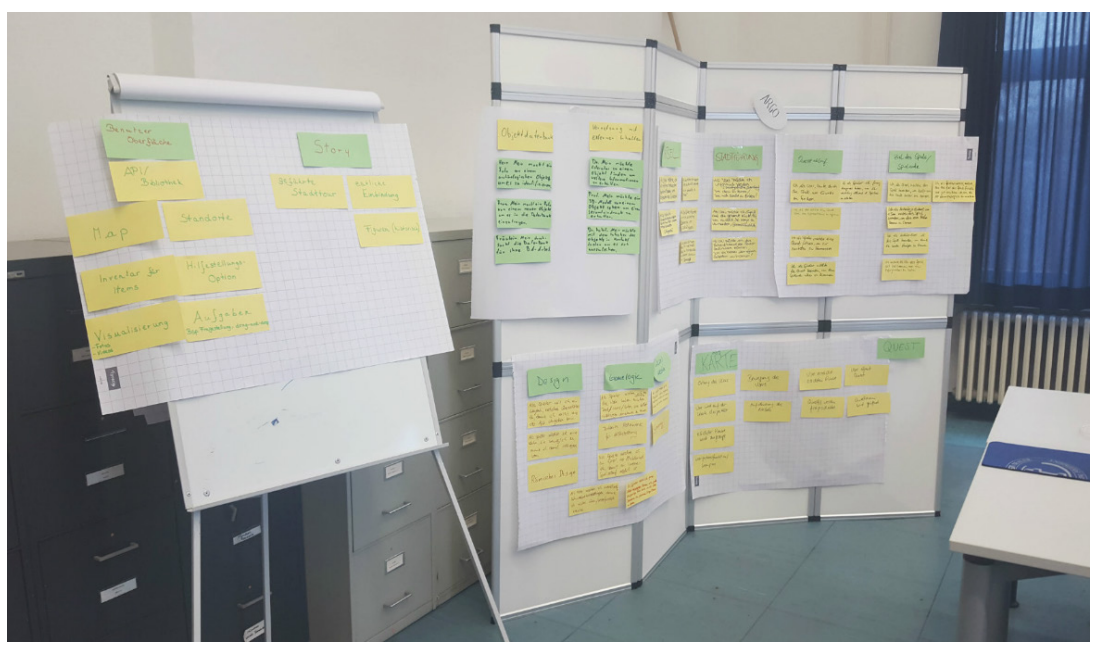

Figure 3: Getting organised. Photo: M. Remmy.

questions to these buildings have to be answered and the price is the climbing of the cursus honorum steps.

'Agrippina op Jöck' focuses on Cologne's founder, Agrippina, who has to successfully play mini games in order to refurbish the city (Figure 5). Agrippina walks through her city and visits Cologne's important landmarks. In order to re-erect or refurbish buildings or city quarters she has to answer questions or play mini games (e.g. jigsaws). The walk through the city within this game is pre-set by the developers. After the last task Agrippina gets an overall view of the buildings that were successfully renewed.

'Mission Barbaricus' leads a retired Roman legionary into the city of Cologne. Unfortunately, he has lost his army diploma and has to ask people for the way to the Roman administration. Right answers bring him closer to the goal; wrong answers make him suspected of being a spy (Figure 6). The walk through the city is also pre-set by the developers. This helps to control the degree of difficulty of the questions. The user is informed of the game's progress by a 'suspicion bar' on the upper rim of the screen.

All games were developed as walks through the city. The desktop versions of the games were the foundation for a later mobile version that would lead the user directly to the Roman remains of Cologne.

On the one hand, the development of geo-games allowed the students to use their expertise in digital media while learning archaeological facts. On the other hand, new impulses were given through the change of learning environment and the use of self-organised learning. Topics such as storytelling, app design and project steering were as important as the archaeological knowledge. Teaching methods such as clustering, project learning and the evaluation of different project sections were used to get the best possible learning outcome. An 


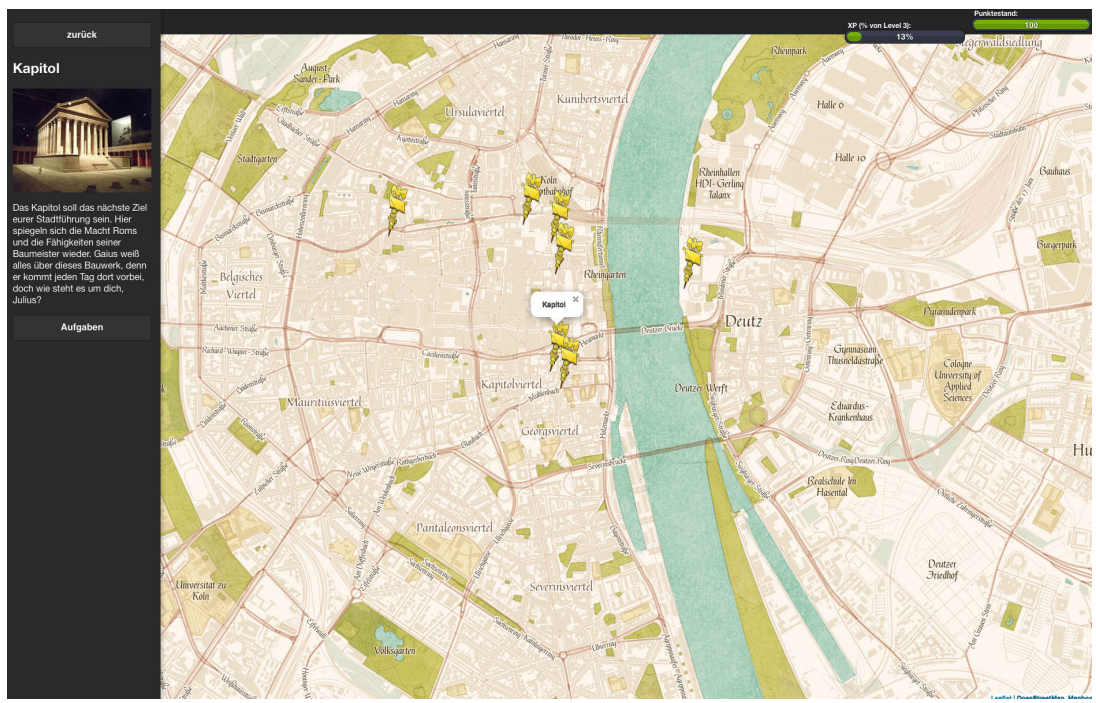

Figure 4: Screenshot 'Life of Julius'.

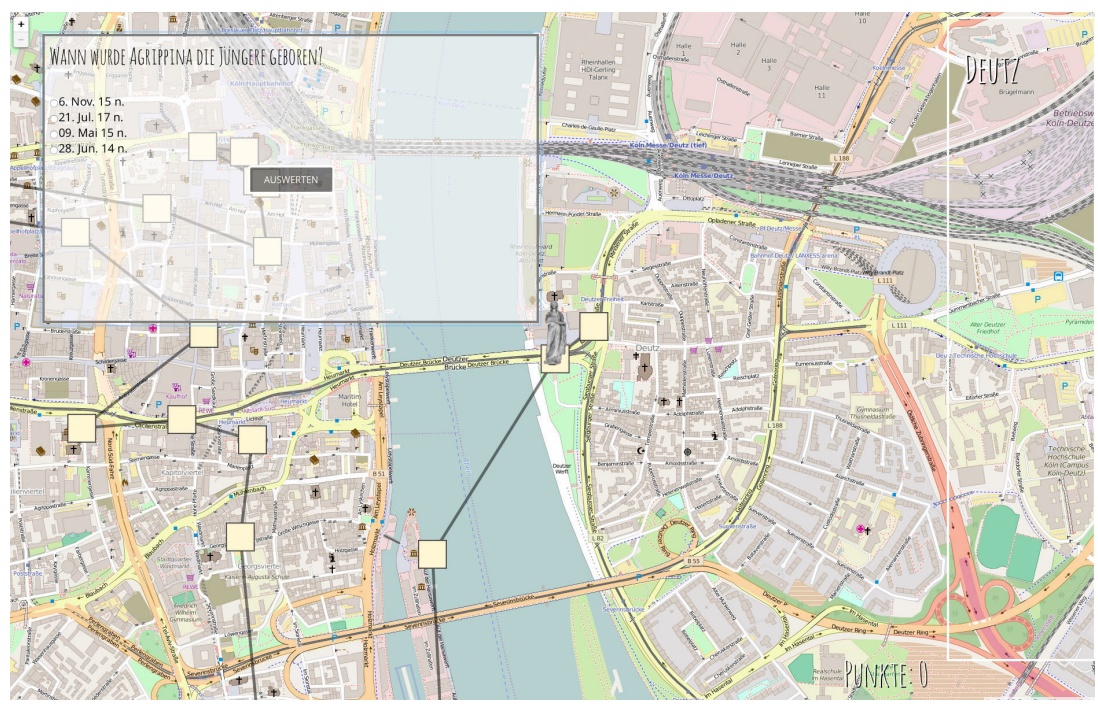

Figure 5: Screenshot 'Agrippina op Jöck'.

accompanying website documented the progress of the seminar and backed up all results, including the code for the tool.

Not all these methods and topics were seen as 'lart pour l'art'. They were chosen to help the students to get a different perspective on the material that they are learning within the curriculum of archaeological or computer science 


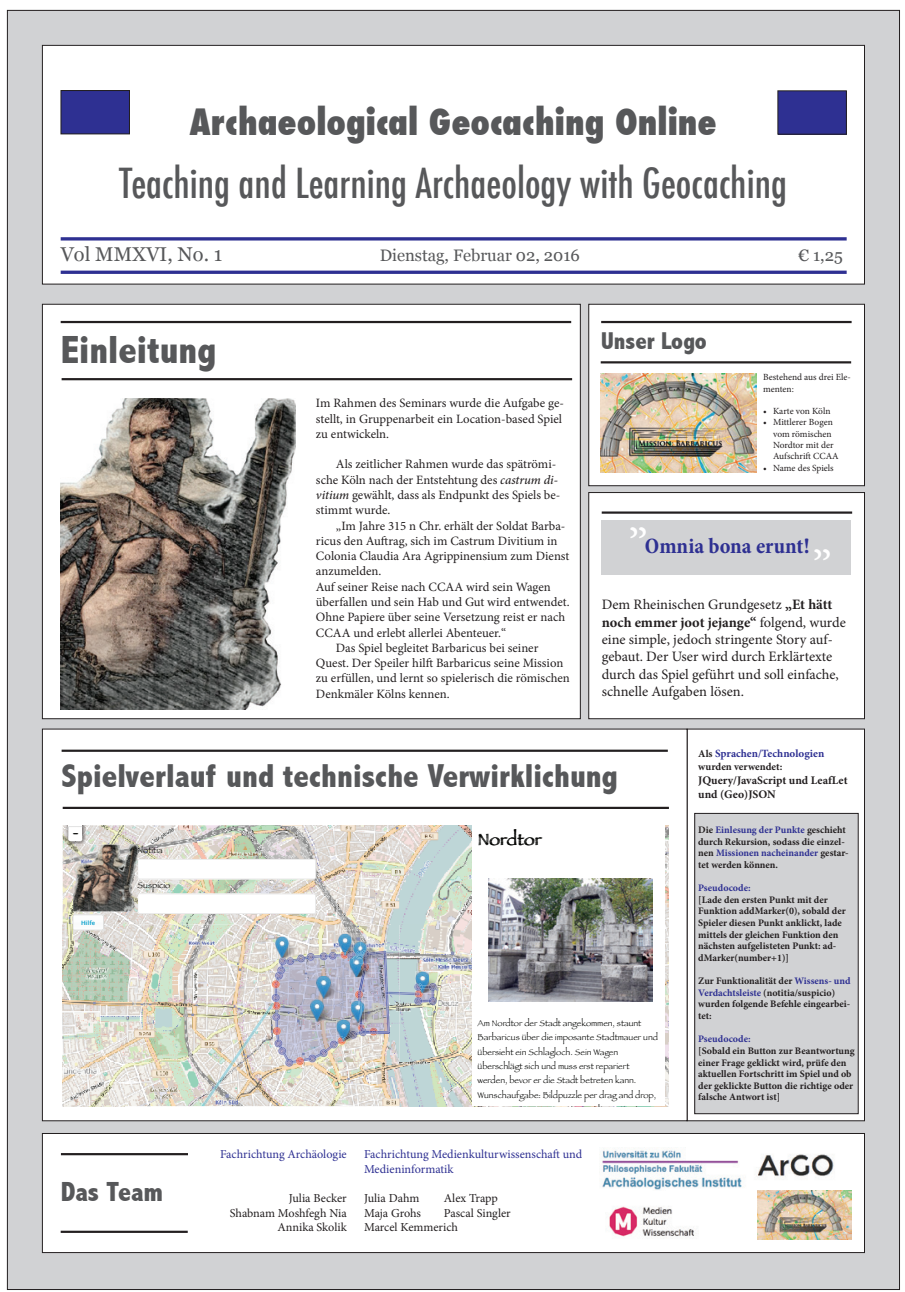

Figure 6: Poster 'Mission Barbaricus'.

subjects. The most important objective was to create a real case scenario for a future job. One future possibility to link a university course to the labour market would be a service-learning offer (Remmy 2016). Of course, with this, the laboratory conditions of our held seminar would make an even bigger impact on the students.

The feedback of the students who attended the seminars was very positive. 'Better motivation', 'learning in an open environment outside the classroom' and 'practical experience usable for later jobs' were the most stated advantages. On the other hand, students wanted 'a seminar over two semesters in order to get more basic knowledge in programming'. Also the 'missing time for the 
creation of a really satisfying product' was demanded. The feedback show that the development of a course like this requires a lot of preparation and experience in teaching. For future courses a questionnaire would be helpful to get feedback on the learning objectives, methods and also the actual outcome of the seminar.

\section{Excursion approach}

The already-stressed paradigm shift from a passive to an active learner can also be transferred to the educational format of excursions. One definition stresses the major goals of excursions: excursion is a form of teaching with the goal of a real encounter with the spatial reality outside the classroom. The purpose of the excursion is to enable the student to directly record geographic phenomena, structures, functions and processes on site (Rinschede 1997: 7-10). Within the excursion didactics the classification of overview excursion, working excursion and tracking excursion shows a significant differentiation (Hemmer \& Uphues 2009) (Figure 7). Educaching approaches can be related to the more active, flexible and reflected excursions.

In our case the students reflected on their work at the end of the seminar and articulated a possible field of use in excursions. The need for a modular system that could be not only used for archaeological topics but referred to other subjects such as art history, politics or history was seen as real asset to the teaching in archaeology.

In a brainstorming session at the end of the seminar, requirements for a future geocaching tool were fixed. The students stressed that a modular system could help to create flexible and non-static tools for teaching and learning. This also leads to an open and possible interdisciplinary approach.

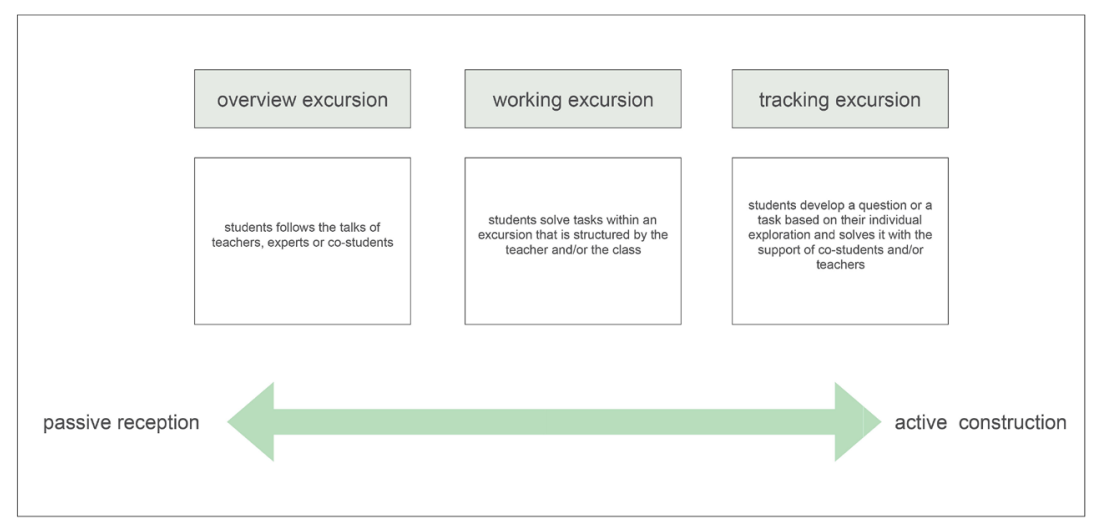

Figure 7: Classification of excursions (after Hemmer \& Uphues 2009). 
An important issue for the students was usability. Intuitive handling at both the front and back end are the key for wider use in university context. Furthermore, ideas of open source and sustainability show the students' providence.

Unfortunately, there was not enough time to create first mock-ups or codes for such a tool. Therefore, we evaluated available systems. In our case, the two related systems Actionbound (Actionbound 2019) and Biparcours (Biparcours 2019) came quite close to the students' requirements. Actionbound is an interactive app-based game approach for smartphones and tablets: players are invited to accomplish tasks, which can be defined through the Bound-Creator on the website actionbound.com, in order to playfully discover their environment by learning more about its history, politics and culture. In contrast to a geocache or a scavenger hunt, Actionbound requires the players to create their own content (Actionbound 2019). Unfortunately, the licences for universities are not free.

Biparcours is funded by the Ministry of North Rhine Westphalia. The app is an interactive learning tool that allows users to perform exciting tasks that need to be solved at certain waypoints: from finding specific points and answering quiz questions to taking your own photos and videos. Since the app is statefunded, it is not possible to use this app outside North Rhine Westphalia.

A proof of concept project was established within a student excursion of the Archaeological Institute to Greece in $2018 .{ }^{4}$ In order to see how stable the system is and how students react to this gamification approach on knowledge sharing, one simple quest in the sanctuary of Olympia (Mallwitz 1972) was developed with the Actionbound application. After minor problems with the GPS signals, all students had the opportunity to try the game and give feedback. Negative aspects were the connection problems and deficiencies in usability. Positive comments refer to the motivation factor as well as the learning environment as key aspects that lead to better learning. In this case the students used their own mobile devices. For future attempts to integrate mobile devices into courses, the support of the university or a foundation is mandatory in order to provide the devices with a similar operating system to all students and create technical and social equality.

\section{Outlook}

As a proof of concept, the seminar showed that an educaching approach in teaching archaeology can be very fruitful. The students' feedback as well as the experience from the teacher's perspective were very positive. However, the integration in the curriculum of archaeological teaching at universities has still to

${ }^{4}$ Special thanks to Prof. Thoralf Schröder and Dr Frank Hulek for the support and Felix Kußmaul for the development of the quests and the support on site. 
be tackled. If there were more test runs with using geocaching in this teaching area, implementation would be easier. The usefulness of this method, especially for excursion seminars, is evident but it is also obvious that the geo-game approach is not sensible for all kinds of seminars or topics but instead has to be seen as tool to set stimuli and get students and teachers engaged. A very important task of teachers and students is the publication of the course's outcomes. This will especially help with the research on this topic, for which compilations of courses held in different universities are very important. However, the field of application surely does not end in the context of higher education at universities. There is more room for experimenting with these methods and this should lead to knowledge transfer in the cultural heritage sector (Rowland 2013) (e.g. museums or landscape or city archaeology) to get the general public involved and attached.

\section{References}

Actionbound (2019). [online] Actionbound Official Website. Available at: https://www.actionbound.com [Accessed 1 April 2019].

Bergmann, J. and Sams, A. (2012). Flip Your Classroom, Washington, DC: ISTE. Bernau, N. (2011). Das Pergamonmuseum und seine vier Museen als Lehrinstrumente einer anderen Moderne. In: R. Grüßinger, V. Kästner and A. Scholl, eds, Pergamon. Panorama der antiken Metropole, Berlin: Imhof, pp. 388-392.

Biparcours (2019). [online] Biparcours Official Website. Available at: http:// biparcours.de [Accessed 1 April 2019].

Bloch, R. (2006). Schwerpunkte gegenwärtiger Entwicklung in der Hochschulbildung. In: P. Pasternak, R. Bloch and C. Gallert, eds, Die Trends der Hochschulbildung und ihre Konsequenzen, Wittenberg: Institut für Hochschulfoschung, pp. 47-100.

Brennan Carrey, T. (2015). cursus honorum. [pdf] Oxford Classical Dictionary. Available at: https://oxfordre.com/classics/view/10.1093/ acrefore/9780199381135.001.0001/acrefore-9780199381135-e-1965 [Accessed 1 April 2019].

Brombach, G. (2010). Vom Geo- zum Educaching. Das Web 2.0 bietet neue didaktische Chancen. [online] dotcomblog. Available at: https://www. dotcomblog.de/wp-content/uploads/downloads/2010/05/educache_ppB. pdf [Accessed 1 April 2019].

Buchegger, B., Krisper-Ullyett, L., Michl, J. and Ortner, J. (2006). Collaborative blended learning. Eine Orientierung für Lehrende, ModeratorInnen und TutorInnen zum Thema: Wie kann ich das E-Medium für Lernprozesse in der Erwachsenenbildung nutzen? Vienna: facultas.

Cacher-Reisen (2019). Cacher-Reisen Official Website. [online] Available at: http://www.cacher-reisen.de/cachearten [Accessed 1 April 2019]. 
Chaney, E. (2000). The Evolution of the Grand Tour: Anglo-Italian Cultural Relations since the Renaissance, London: Routledge.

Curlie (2018). [online] Curlie Official Website. Available at: https://curlie.org/ Science/Earth_Sciences/Geomatics/Global_Positioning_System [Accessed 1 April 2019].

Educaching (2012). [online] Educaching Official Website. Available at http:// www.educaching.com [Accessed 1 April 2019].

Fischer, Th. and Trier, M. (2013). Das römische Köln. Cologne: Bachem.

Geocaching (2000). [online] Geocaching Official Website. Available at: https:// www.geocaching.com/about/history.aspx [Accessed 1 April 2019].

GeoJson (2016). [online] GeoJson Official Website. Available at: https://geojson. org [Accessed 1 April 2019].

Hand, B. (2016). Designing Successful Gamification Practices in Higher Education. [online] GettingSmart. Available at: http://www.gettingsmart.com/2016/12/ gamification-successes-and-failures-higher-education [Accessed 1 April 2019].

Hemmer, M. and Uphues, R. (2009). Zwischen passiver Rezeption und aktiver Konstruktion - Varianten der Standortarbeit am Beispiel der Großwohnsiedlung Berlin-Marzahn. In: M. Nickel and G. Glasze, eds, Vielperspektivität und Teilnehmerzentrierung - Richtungsweiser der Exkursionsdidaktik, Vienna: LIT, pp. 39-50.

Ihamäki, P. (2014). Evolving letterboxing game on Pori Cultural Heritage Road: Emerging challenges for teachers. International Journal of Teaching and Case Studies, 4(4): 354-366.

Kelly, M. (2019). Lectures in Schools - Pros and Cons. [online] ThoughtCo. Available at: https://www.thoughtco.com/lecture-pros-and-cons-8037 [Accessed 1 April 2019].

Kissinger, T., Naumann, S. and Siegmund, A. (2016). Vom Geocaching zum Educaching. Potential und Nutzen von digitalen Geomedien im Rahmen von Outdoor Education. In: J. von Au and U. Gade, eds, Raus aus dem Klassenzimmer: Outdoor Education als Unterrichtskonzept, Weinheim/Basel: Beltz, pp. 111-118.

Kyriakova, G., Angelova, N. and Yordanova, L. (2017). Gamification in Education. [pdf] Stellenbosch University. Available at: https://www.sun.ac.za/ english/learning-teaching/ctl/Documents/Gamification\%20in\%20education.pdf [Accessed 1 April 2019].

Leaflet (2017). [online] Leaflet Official Website. Available at: https://leafletjs. com [Accessed 1 April 2019].

Mallwitz, A. (1972). Olympia und seine Bauten, Darmstadt: WBG.

Mocinic, S.N. (2012). Active teaching strategies in higher education, [pdf] Available at: https://hrcak.srce.hr/file/124604 [Accessed 1 April 2019].

Oxford Dictionaries (2019). [online] Oxford Dictionary Official Website. Available at: https://en.oxforddictionaries.com/definition/gamification [Accessed 1 April 2019]. 
Remmy, M. (2016). Manus manum lavat - the idea of service learning and research-based-learning in archaeology. In: I. Pinto, ed., Entre ciência e cultura: da interdisciplinaridade à transversalidade da arqueologia, Actas das VIII Jornadas de Jovens em Investigação Arqueológica, Lisbon, pp. 529-546.

Rinschede, G. (1997). Schülerexkursionen im Erdkundeunterricht - Ergebnisse einer empirischen Erhebung bei Lehrern und Stellung der Exkursionen in der fachdidaktischen Ausbildung. In: Regensburger Beiträge zur Didaktik der Geographie II, Regensburg: University Regensburg. pp. 7-80.

Robison, D. (2011). Geocache adventures: Ubiquitous handheld computing as an aid to promote environmental awareness amongst students. International Journal of Innovation and Leadership in the Teaching of Humanities, 1(2): 47-56.

Rowland, M. (2013). Geocaching and cultural heritage. The Artefact: Journal of the Archaeological and Anthropological Society of Victoria, 36: 3-9.

Scheding, P. and Remmy, M. (2014). Antike Plastik 5.0://. 50 Jahre Forschungsarchiv für Antike Plastik in Köln, Berlin: LIT, pp. 182-221.

Schleicher, Y. (2006). Digitale Medien und E-Learning motivierend einsetzen. In: H. Haubrich, ed., Geographie unterrichten lernen. Die neue Didaktik der Geographie konkret, Munich: Oldenbourg Schulbuchverlag, pp. 207-222.

van Treeck, T., Himpsl-Gutermann, K. and Robes, J. (2013). Offene und partizipative Lernkonzepte. E-Portfolios, MOOCs und Flipped Classrooms. In: M. Ebner and S. Schön, eds, Lehrbuch für Lernen und Lehren mit Technologien (L3T). [pdf] Available at: http://13t.eu/homepage/das-buch/ebook-2013/kapitel/o/ id/149/name/offene-und-partizipative-lernkonzepte [Accessed 1 April 2019].

Vorster, C., Satzinger, G., Luckhardt, J. and Döring, T. (2018a). Die Antikenalben des Alphons Ciacconius in Braunschweig, Rom und Pesaro, Braunschweig: Herzog Anton-Ulrich- Museum und Autoren, pp. 8-276.

Vorster, C. (2018b). Die Zeichnungsalben des Alphons Ciacconius und ihr Zeugniswert für Antikensammlungen des 16. Jahrhunderts. Kölner Jahrbuch, 51: 463-481.

Wannemacher, K., Jungermann, I., Scholz, J., Tercanli, H., von Villiez, A. (2016). Digitale Lernszenarien im Hochschulbereich. In: K. Wannemacher, ed. Hochschulforum Digitalisierung Arbeitspapier, 15. [pdf] Hochschulforum Digitalisierung. Available at: https://hochschulforumdigitalisierung.de/sites/ default/files/dateien/HFD\%20AP\%20Nr\%2015_Digitale\%20Lernszenarien. pdf [Accessed 1 April 2019].

Wildt, J. (2009). Forschendes Lernen: Lernen im 'Format' der Forschung. journal hochschuldidaktik, 20(2): 4-7.

Winckelmann, J.J. (1756). Gedanken über die Nachahmung der griechischen Werke in der Malerey und Bildhauerkunst, Dresden/Leipzig: Walther.

Winckelmann, J.J. (1760). Description des pierres gravées de feu Baron de Stosch, Florenz. 